\title{
Risk Taking Analysis of Beginner Investors in East Java Indonesia
}

\author{
Damayanti ${ }^{1}$ \\ \{damayanti_rahmania@yahoo.co.id $\left.{ }^{1}\right\}$ \\ Department of Management, Sekolah Tinggi Ilmu Ekonomi YPPI Rembang, Indonesia ${ }^{1}$
}

\begin{abstract}
This study is to determine financial behavior, especially risk taking of beginner investors in East Java, Indonesia. It is to test the variables of financial literacy, overconfidence and risk perception that affect the risk taking of beginner investors. The population in this study was all beginner investors in East Java, Indonesia. The sampling technique used was purposive sampling, using a sample of 150 respondents. This study used a survey and the analysis technique used was multiple linear regressions. The results showed that financial literacy had a significant positive effect on risk taking, overconfidence had a significant positive effect on risk taking but risk perception had a significant negative effect on risk taking. Based on the research results, it shows that financial literacy, overconfidence and risk perception are important factors that must be considered in making risk decisions, especially in the application of risk management.
\end{abstract}

Keywords: risk taking, beginner investors, financial literacy, overconfidence, risk perception

\section{Introduction}

The current situation and business environment has been unpredictable, complex and always changeable during the business process. This uncertain business process creates some risks that must be faced by business people. According to Cooper and Faseruk [1], risk is defined as an opportunity for the owner to lose from the results of a person's decision making. Normative decision theory assumes that people estimate the risks and rationally make choices in uncertainty conditions. Meanwhile, expected utility theory explains how someone should act when making decisions in uncertainty, that is, by maximizing their utility. Every investor, whether in risk averse or not, will always maximize the expected utility of his welfare. The role of expected utility can be used to introduce economic decision choices to uncertain circumstances. Decision making is done by measuring the obtained outcome with the probability level to calculate the level of expected utility of all available alternatives.

According to Frank [2] managers will choose less risk if being asked to take risks and given an advantage as a consequence. Risk behavior management, with consideration of utility, and propensity to accept risk, strategic risk is very important for investors to protect them from failing to invest. Based on risk expectations and preferences, the investors need to compare investment alternatives to others. This is in line with the research by Fiegenbaum and Thomas [3], which took a sample of company managers. With regard to efforts to minimize the risk in decision making, effective risk management is needed. 
This study examines the influence of the variables of financial literacy, overconfidence, and risk perception to reduce the level of risk in risk taking, and to increase utility. The novelty of this research is that it examines the factors influencing risk taking; meanwhile the difference of this study from previous research is that it focuses on the population, namely beginner investors. The researcher is interested in examining beginner investors because they do not have experience and to know whether or not financial literacy, overconfidence and risk perception of investors affect risk taking or not. The researcher also wants to prove whether the heuristic theory has applied in Indonesia. As we know, heuristic theory explains a person's behavior in making decisions with a limited and short time, and there is only limited information in which all of them are in uncertain conditions (Ackert and Deaves) [4]. Furthermore, Tversky and Kahneman [5] proposed that people used a number of heuristics to reduce the assessment to make it simpler when they faced something difficult to assess probability or frequency. Ackert and Deaves [4] argues that making quick decisions involves elements of perception, memory, framing effects and the ease of processing information and the overloaded condition of informants.

The first variable in this study is financial literacy. Huston [6] argues that financial literacy is a component of human capital that can be used in financial activities to increase expected lifetime utility (behavior that increases financial welfare). According to Wang [7], there are two main things in the financial literacy literature to explain the relationship between financial literacy and risk taking in investment. First, good financial behavior is positively correlated with higher levels of financial literacy (Edmiston) [8]. Second, financial education and experience positively affect financial literacy and behavior (Lyons et al.,) [9]. The research results of Cavezzali et al., [10] explain that understanding the individual's low ability to diversify a portfolio can depend on general financial knowledge. Their research results show that financial literacy and financial education affect the dimension of risk taking (portfolio risk).

The second variable is overconfidence. Ackert and Deaves [4] state that overconfidence is the tendency for people to overestimate their knowledge, ability and accuracy of information, or being too optimistic about the future and their ability to control. Barber and Odean [11] stated that the high volume of trading is because of overconfidence. Investors' overconfidence is assumed to overestimate the value of their personal information, and it causes them to trade too actively and, consequently, they make little profit. The results of the research by Nosic and Weber [12] show that overconfidence, namely miscalibration, has an effect on risk taking.

The third variable is risk perception. According to Sitkin and Weingart [13], risk perception indicates an individual's assessment of risk measure in the uncertainty of investment returns. A high level of risk perception indicates a very high individual assessment of investment risk. This makes investors tend to assume that investment returns will be negative compared to the variability of actual investment returns. Kahneman and Tversky [14] argued that if an investor considers profit more than risk, the investor is a risk seeker. Cooper and Faseruk [1], in their research, stated that high-risk perceptions lead to low risk-taking behavior, and vice versa.

Based on the explanation, the research problems can be formulated as the followings:

- How does financial literacy affect the risk taking of beginner investors in East Java?

- How does overconfidence affect the risk taking of beginner investors in East Java?

- How does risk perception affect the risk taking of beginner investors in East Java?

This research is expected to be a reference for investors, especially beginner investors, as a basis for making decisions, especially those related to risk management. This research provides benefits in risk management by paying attention to financial literacy, overconfidence and risk perception, and risk taking in making investment decisions. In addition, the results of this study 
can assist investors to design strategic risk in decision making by considering the factors that affect risk taking so that they are able to carry out effective risk management.

\section{Method}

The research method belongs to quantitative research, which is used to answer the research problems and to test hypotheses based on previous theory and research. The quantitative research method is a research method based on the positivism philosophy.

\subsection{Population and sample}

The population in this study was all beginner investors in East Java, Indonesia. The number of populations is not certain. Ghozali [15] states that the number of samples in the estimation method using Maximum Likelihood (ML) requires a minimum sample of 100, but not above 400 or 500 samples. The samples collected and used in this study were 150 samples. The sampling technique used a purposive sampling method. The criteria used in this study are: (1) beginner investors are those who have been trading and investing their capital in trading shares on the Indonesia Stock Exchange, and (2) beginner investors are those who have been trading for less than a year.

\subsection{Operational definition of research variables}

The independent variables in this research include:

- Financial Literacy

Financial literacy includes basic knowledge of finance, financial management, savings and investment, and risk management Kiliyanni and Sivaraman [16]. Indicators of financial literacy variables that refer to the research of Kiliyanni and Sivaraman [16], include: (a) basic knowledge, (b) money management, (c) saving and investment, and (d) risk management

- Overconfidence

Ackert and Deaves [4] Overconfidence is the tendency for people to overestimate their knowledge, ability, and accuracy of information, or to be too optimistic about the future and their ability to control. The indicators of the overconfidence variable referring to the research of Khan, et al. [17], include: (a) relative financial domain optimism, (b) personal investment optimism, (c) illusion of control, and (d) better than average.

- $\quad$ Risk Perception

According to Cooper and Faseruk [1], risk perception is a decision maker's assessment of the risks inherent to a situation. Indicators from risk perception variables referring to the research of Cooper and Faseruk [1], include: (a) ethical, (b) investment, (c) gambling, (d) healthy/ safety, (e) recreational, and (f) social item.

The dependent Variable in this research is risk taking. Risk taking is the behavior of investors in taking risks (Nosic and Weber) [12]. Indicators of risk taking variables which refer to the research of Weber, et al. [18], include: (a) ethical, (b) financial, (c) healthy/ safety, (d) recreational, and (e) social item. 


\subsection{Type and source of data}

This research is an empirical study, which is a study of empirical facts obtained based on observation or experience. It used interval data type and a survey to get some responses from the questionnaire provided by the researcher. The data source used in this study was primary data, namely the data obtained from the original source (not through intermediary media). The primary data of this study were obtained through a questionnaire distributed to a sample of investors.

\subsection{Procedure of data collection}

This study used data collection techniques by providing a questionnaire, which was filled out by investors to find out their responses to the subject under the study. Respondents, in this case, were asked to fill out the questions or statements in the questionnaire.

\subsection{Instrument testing}

The instrument test includes two tests, namely the reliability test and the validity test. In this instrument testing, there were 20 respondents to be tested for reliability and validity.

\subsection{Technique of data analysis}

The data analysis technique used multiple linear regression analysis. This analysis is used to examine the effect of financial literacy, overconfidence and risk perception on the risk taking of beginner investors. Partial test or $t$ test basically shows how far the influence of one independent variable individually in explaining the dependent one. Regression model used can be formulated by the following equation, see equation (1) for an example:

$$
\mathrm{Y}=\alpha+\beta 1 \mathrm{X} 1+\beta 2 \mathrm{X} 2+\beta 3 \mathrm{X} 3+\mathrm{e}
$$

$\begin{array}{ll}\text { Note: } & \\ \text { Y } & \text { : Risk Taking } \\ \mathrm{X} 1 & \text { : Financial Literacy } \\ \mathrm{X} 2 & \text { : Overconfidence } \\ \mathrm{X} 3 & \text { : Risk Perception } \\ \beta 1, \beta 2, \beta 3, \beta_{4}, \beta 5 & \text { : Regression Coefficient } \\ \mathrm{e} & \text { : Error }\end{array}$

\section{Results and discussion}

\subsection{Result}

\subsubsection{Instrument testing}

In this study, the instrument was tested on 20 respondents first to assess the appropriateness of the statements in the questionnaire. Based on the results of the reliability test, it shows that 
all variables pass the reliability test. It can be seen in Table 1 in which the Cronbach's alpha value is above 0.7 .

Table 1. The Result of Reliability Testing

\begin{tabular}{cc}
\hline Variable & Cronbach's Alpha \\
\hline Financial Literacy & 0.701 \\
Overconfidence & 0.791 \\
Risk Perception & 0.837 \\
Risk Taking & 0.812 \\
\hline
\end{tabular}

Then, based on the results of the validity testing, the explanation of each variable is as follows:

- Financial literacy. The results of the validity testing show that all statements on the financial literacy variable in the study are valid. They also pass the validity test and deserve to be continued.

- Overconfidence. The results of the validity testing show that all statements on the overconfidence variable are valid; they pass the validity testing and deserve to be continued.

- $\quad$ Risk Perception. The results of the validity testing show that all statements on risk perception variables are valid; they pass the validity testing and deserve to be continued.

- Risk Taking. The results of the validity testing show that all statements on the risktaking variable are valid; pass the validity testing and deserve to be continued.

\subsubsection{Regression testing}

The results of the multiple linear regression testing can be seen in Table 2:

Table 2. The Result of Multiple Linear Regression Test

\begin{tabular}{ccccl}
\hline No & Variable & t-account & Sig. P Value & \multicolumn{1}{c}{ Conclusion } \\
\hline 1 & Financial Literacy & 3.763 & .000 & $\begin{array}{l}\text { Financial Literacy affects the risk } \\
\text { taking of beginner investor }\end{array}$ \\
\hline 2 & Overconfidence & 2.853 & .005 & $\begin{array}{l}\text { Overconfidence affects the risk taking } \\
\text { of beginner investor }\end{array}$ \\
\hline 3 & Risk Perception & -3.104 & .002 & $\begin{array}{l}\text { Risk Perception affects the risk taking } \\
\text { of beginner investor }\end{array}$ \\
\hline
\end{tabular}

The results of multiple linear regression statistical test show that financial literacy, overconfidence and risk perception factors affect the risk taking of beginner investors in East Java, Indonesia. The regression equation can be formulated as follows (2):

$$
Y=0,756+3.763 X_{1}+2.853 X_{2}-3.104 X_{3}+0,640
$$

Based on the research results shown by the equation above, the meaning of the equation is if the financial literacy variable is increased by one unit, it will increase risk taking by 3,763 . If the overconfidence variable is increased by one unit, it will increase risk taking by 2,853 . If the risk perception variable is increased by one unit, it will reduce risk taking by 3.104 . 


\subsubsection{Determination testing}

Based on the results of the study, it shows that the Adjusted R square has a value of 0.242. It means that the factors examined in this study including financial literacy, overconfidence and risk perception have an influence on the risk taking of beginner investors by $24.2 \%$, while the remaining of $75.8 \%$ is influenced by other factors outside the model. This means that the results of the study statistically do not show the influence because the score is below $50 \%$.

\subsection{Discussion}

The discussion of each factor affecting the risk taking of novice investors is as follows:

\subsubsection{The influence of financial literacy on risk taking of beginner investors}

The results show that financial literacy has a positive effect on risk taking. It means that if investors' knowledge of financial literacy is high, they are risk seekers (dare to take risks). The high-risk taking behavior of investors will be proven by investing in risky assets greater than the amount of investment in risk-free assets. In other words, the investors dare to invest in risky assets. On the other hand, the results of the research show that the lower the level of investor financial literacy, the lower the risk taking of investors.

Investors who have low financial knowledge tend not to dare to choose risky investment options. The research results of Aren and Zengin [19] showed that if the level of financial literacy of investors is low, the investors prefer small risky investments. On the contrary, when the level of financial literacy increases, they tend to create portfolios or buy equity. The results of this study are consistent with the research of Wang, et al. [7], Carey, et al. [20], Cavezzali and Gardenal [10]. Good financial behavior is positively correlated with higher levels of financial literacy [8]

\subsubsection{The effect of overconfidence on beginner investors risk taking}

The results showed that overconfidence has a positive effect on risk taking, meaning that if the investors have a high level of overconfidence, they will be risk seekers (dare to take risks). The investors with high confidence of knowledge and information will have the courage to take risks (risk seekers). Conversely, if the lower the level of overconfidence, they will reduce the level of investor risk taking. Meanwhile, the investors who have low confidence in their information, they will not dare to take risks (risk averse).

This research is in accordance with the results of research by Odean [21], Odean [22], and Nosić and Weber [12]. Odean [21] argued that someone who is overconfident will be a risk seeker. The results of Odean [22] research showed that investors who are overconfident have a tendency to overestimate the accuracy of the information they have, so they become less careful and underestimate risks. It means that if an investor's level of overconfidence is higher, the investor will then be a risk seeker.

\subsubsection{The influence of risk perception on risk taking of beginner investors}

The results showed that risk perception has a negative effect on risk taking. It means that the higher the level of investor's risk perception, the lower the level of investor risk taking. This shows that if investors assess and perceive an investment as high, then in making decisions the 
risk tends to be risk averse. Conversely, the lower the investor's risk perception level, the investor will increase the level of investor risk taking. It shows that if the investors assess and assume that investment is low, they will dare to take risks (risk seekers).

The results of this study are in line with the research by Traczyk, et al. [23], Nosić and Weber [12] and Cooper and Faseruk [1]. Traczyk, et al. [23] emphasized that the decision to engage in risky behavior or not is causally determined by risk perceptions. Furthermore, Nosić and Weber [12] argued that risk-taking behavior is determined by risk perception. The person's high perception of risk can cause him to tend to avoid risk, so he will choose to invest in risky assets with a small amount. Cooper and Faseruk [1] argued that high risk perceptions lead to low risk-taking behavior, and vice versa.

\section{Conclusion}

The results of this study indicate several things. First, the risk-taking model in this study is acceptable. The three hypotheses are all accepted. Second, the financial literacy variable gives the greatest effect compared to the overconfidence and risk perception variables on the risk taking of beginner investors. It shows that the investors financial knowledge and literacy will greatly influence their financial decision making. It is very important for them, especially beginners, to continue to improve their financial literacy, so that they will get maximum benefits in investing Kahneman and Tversky [24], proposed that to make decisions, in various situations, a person begins with a belief which is then adjusted to the information available to make a final decision. Third, risk perception factor also affects investors' risk taking followed by overconfidence. In accordance with the heuristic theory, an investor also considers experience, perception, memory, framing effect and ease of processing information. Fourth, investors who have good knowledge will become overconfidence so that they assess the risk is low, so that they dare to take high risk (risk seekers). This is in association with the heuristic theory, where investors make risk decisions based on the level of confidence they have. The results showed that they tend to make decisions quickly based on the level of confidence and experience they have.

The limitations of this research and future research developments are described as follows. First, this study only uses a portion of the investors in East Java, so the results of the study cannot be generalized to all investors in Indonesia. Second, this study only takes a population with a limit of beginner investors in stock investment, so it cannot represent investors in general. Whereas investment is not only investing in stocks, it can also be other investments, for example investments in the form of savings, deposits, bonds, mutual funds and other investments. Third, further research might be possible to develop studies on the factors that influence this risk taking by expanding the location, unit of analysis as well as developing research variables and indicators. Also, it can add other variables affecting risk taking, for example experience, risk preferences and other variables.

\section{Acknowledgement}

This research work is supported by Sekolah Tinggi Ilmu Ekonomi YPPI Rembang, Indonesia. 


\section{References}

[1] T. Cooper and A. Faseruk, "STRATEGIC RISK, RISK PERCEPTION AND RISK BEHAVIOUR: META-ANALYSIS," Journal of Financial Management \& Analysis, vol. 24, 2011.

[2] L. Frank, "Our Perception of Risk," Corporate Finance Review, vol. 12, pp. 24-26, 2008.

[3] A. Fiegenbaum and H. Thomas, "Attitudes toward risk and the risk-return paradox: prospect theory explanations," Academy of Management journal, vol. 31, pp. 85-106, 1988.

[4] L. F. Ackert and R. Deaves, "Behavioral finance," South-Western Cengage, 2010.

[5] A. Tversky and D. Kahneman, "Availability: A heuristic for judging frequency and probability," Cognitive psychology, vol. 5, pp. 207-232, 1973.

[6] S. J. Huston, "Measuring financial literacy," Journal of consumer affairs, vol. 44, pp. 296-316, 2010.

[7] J. Wang, D. Duncan, Z. Shi, and B. Zhang, "WEB-based gene set analysis toolkit (WebGestalt): update 2013," Nucleic acids research, vol. 41, pp. W77-W83, 2013.

[8] K. D. Edmiston, Gillett, M. C. \& Fisher, "Financial Education at The Workplace, Evidence From a Survey of Federal Reserve Bank Employees. Part I: Knowledge and Behavior," Community Affairs Working Paper. , 2006

[9] A. C. Lyons, Y. Chang, and E. Scherpf, "Translating financial education into behavior change for low-income populations," Journal of Financial Counseling and Planning, vol. 17, 2006.

[10] E. Cavezzali and G. Gardenal, "Risk governance and performance of the Italian banks: An empirical analysis," Department of Management, Università Ca'Foscari Venezia Working Paper, 2015.

[11] B. M. Barber and T. Odean, "Boys will be boys: Gender, overconfidence, and common stock investment," The quarterly journal of economics, vol. 116, pp. 261-292, 2001.

[12] A. Nosić and M. Weber, "How riskily do I invest? The role of risk attitudes, risk perceptions, and overconfidence," Decision Analysis, vol. 7, pp. 282-301, 2010.

[13] S. B. Sitkin and L. R. Weingart, "Determinants of risky decision-making behavior: A test of the mediating role of risk perceptions and propensity," Academy of management Journal, vol. 38, pp. 1573-1592, 1995.

[14] D. Kahneman and A. Tversky, "On the interpretation of intuitive probability: A reply to Jonathan Cohen," 1979.

[15] I. Ghozali, "Model Persamaan Structural: Konsep dan Aplikasi dengan program AMOS 24, Update Bayesian SEM," Badan Penerbit Universitas Diponegoro, 2017.

[16] A. L. Kiliyanni and S. Sivaraman, "The perception-reality gap in financial literacy: Evidence from the most literate state in India," International Review of Economics Education, vol. 23, pp. 47-64, 2016.

[17] M. Khan, H. H. Ngo, W. Guo, Y. Liu, L. D. Nghiem, F. I. Hai, et al., "Optimization of process parameters for production of volatile fatty acid, biohydrogen and methane from anaerobic digestion," Bioresource technology, vol. 219, pp. 738-748, 2016.

[18] E. U. Weber, A. R. Blais, and N. E. Betz, "A domain-specific risk-attitude scale: Measuring risk perceptions and risk behaviors," Journal of behavioral decision making, vol. 15, pp. 263-290, 2002.

[19] S. Aren and A. N. Zengin, "Influence of financial literacy and risk perception on choice of investment," Procedia-Social and Behavioral Sciences, vol. 235, pp. 656-663, 2016.

[20] L. A. Carey, C. M. Perou, C. A. Livasy, L. G. Dressler, D. Cowan, K. Conway, et al., "Race, breast cancer subtypes, and survival in the Carolina Breast Cancer Study," Jama, vol. 295, pp. 2492-2502, 2006.

[21] T. Odean, "Volume, volatility, price, and profit when all traders are above average," The journal of finance, vol. 53, pp. 1887-1934, 1998.

[22] T. Odean, "Do investors trade too much?," American economic review, vol. 89, pp. 1279-1298, 1999.

[23] J. Traczyk, A. Sobkow, and T. Zaleskiewicz, "Affect-laden imagery and risk taking: the mediating role of stress and risk perception," PloS one, vol. 10, p. e0122226, 2015.

[24] D. Kahneman and A. Tversky, "On the psychology of prediction," Psychological review, vol. 80, p. 237, 1973. 